\title{
NF-Kappa-B Inhibitor Zeta
}

National Cancer Institute

\section{Source}

National Cancer Institute. NF-Kappa-B Inhibitor Zeta. NCI Thesaurus. Code C150036.

NF-kappa-B inhibitor zeta (718 aa, $78 \mathrm{kDa}$ ) is encoded by the human NFKBIZ gene. This protein plays a role in the inhibition of nuclear factor kappa-B-mediated gene transcription. 